\title{
The Effect of Accounting Disclosure and Environmental Performance, Company Size and Corporate Social Responsibility Disclosure on the Value of Mining Companies Listed on the Indonesia Stock Exchange 2015-2019
}

\author{
Fikry Tanjung1, Rina Br Bukit ${ }^{1}$, Khaira Amalia Fachrudin ${ }^{1}$ \\ ${ }^{1}$ Department of Accounting, Faculty of Economics and Business at Universitas Sumatera Utara, Indonesia
}

Corresponding Author: Fikry Tanjung

\begin{abstract}
This study analyzes the effect of environmental accounting disclosure, environmental performance disclosure, company size, and corporate social responsibility disclosure on firm value in mining companies listed on the IDX. This study uses an associative clause design. This research's population and sample are mining companies that publish annual reports and sustainability reports during 20152019, totaling 18 mining companies using the purposive sampling method. The number of analysis units used is 90 . This study's type of data is secondary data obtained from the IDX website, namely www.idx.co.id. The data analysis technique uses multiple linear regression analysis using the eViews 10 application program. This study indicates that simultaneously environmental accounting disclosure, environmental performance disclosure, company size, and corporate social responsibility disclosure of firm value. However, partially, environmental accounting disclosure has a positive and insignificant effect on firm value, environmental performance disclosure has a negative and insignificant effect on firm value, firm size has no significant positive effect on firm value, and disclosure of corporate social responsibility has a negative but significant effect on firm value.
\end{abstract}

Keywords: Firm Value, Environmental Accounting Disclosure, Environmental
Performance Disclosure, Company Size, Corporate Social Responsibility Disclosure

\section{INTRODUCTION}

The company is an organization founded to make a profit. A company must improve its performance to increase company value to maintain its continuity with the increasing competition level. Company value can increase not only because of excellent financial performance, but companies must also pay attention to the social, economic, and environmental impacts of company activities, such as pollution and depletion of natural resources. Therefore, companies must be more effective and efficient in using available natural resources to survive the company in the future. The company's value can increase sustainably due to good financial performance because investors in making investment decisions look at financial performance and consider corporate sustainability that is guaranteed if the company also cares about the social, economic, and environmental surroundings of the company operations.

Corporate sustainability aims to maximize profit and care for the preservation of nature (planet) and society (people). Currently, the government is focusing on development and community welfare. One of the government's steps to 
Fikry Tanjung et.al. The effect of accounting disclosure and environmental performance, company size and corporate social responsibility disclosure on the value of mining companies listed on the Indonesia stock exchange 2015-2019.

make it happen is to support the MDGs (Millennium Development Goals) program. The MDGs program has 17 objectives, 169 targets, and 241 indicators. Therefore, support from all parties is needed to overcome climate change problems caused by environmental damage due to the company's operational activities. The 17 goals of the MDGs program are in line with the triple bottom line concept, which states that the business world is not only pursuing profit or contributing economically (profit) but also must preserve the environment (planet) and the achievement of human welfare (people) (Elkington, 1997).

Bradshaw et al. (2010) state that Indonesia is ranked fourth globally as a country that contributes to environmental damage. In 2012, there has been a decrease in Indonesia's primary forest, covering an area of 0.84 Mha, higher than Brazil, which is 0.6 Mha (Margono et al., 2015). There are seven indicators of causes of environmental degradation, namely loss of natural forest; habitat conversion; fishing and other sea catching; use of chemical fertilizers; water pollution; carbon emissions, and; threats to species. Of the seven indicators of the causes of environmental degradation, one of Indonesia's concerns is the loss of natural forests, mainly due to mining companies' activities, particularly open-pit mining.

This study selects the type of company in the mining industry sector because this industrial sector is one of Indonesia's economic activity pillars. However, on the other hand, this industrial sector is also the one that causes environmental damage due to mining operations. In an article published by FWI in March 2015, it was stated that one of the industrial sectors in Indonesia that causes forest cover loss in the mining industry sector, of course, this can cause environmental damage and global warming. Nearly $34 \%$ of land in Indonesia is handed over and managed by corporations through mining permits. Likewise, around 3.97 million ha of protected forest areas are under threat due to forest exploitation and mining activities (Messwati, 2012). Most of the mining activities use the open-pit mining method to carry out their production activities, namely by clearing forest lands on a large scale to extract minerals from the ground, resulting in deforestation, deforested forests, eroded soil, and leaving large holes on the land.

Apart from the impact on the environmental damage caused by exploration and mining operations, mining companies' risk is the risk of fluctuations in commodity prices of mining goods in the world commodity market (Indrajaya and Setiadi, 2011). The following is a graph of commodity prices based on Australian Thermal Coal data for 2015-2019:

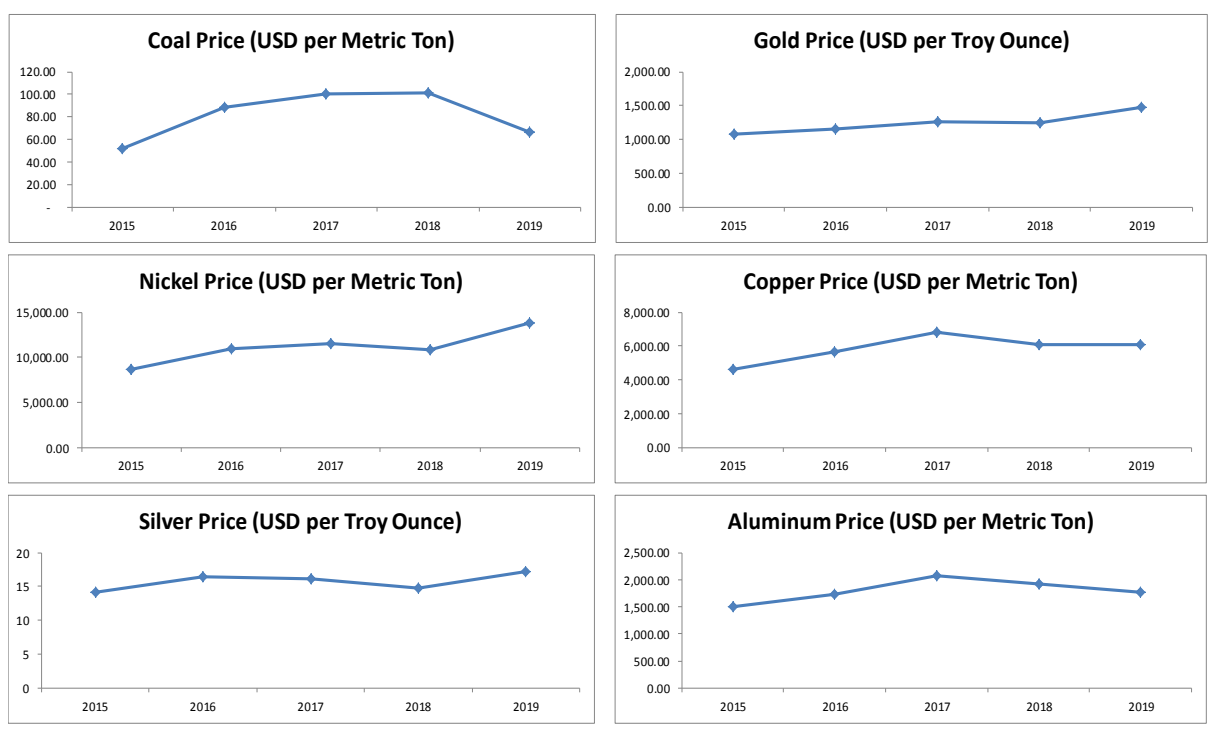

Figure 1 Mining commodity prices 2015-2019, www.indexmundi.com/commodities 
Fikry Tanjung et.al. The effect of accounting disclosure and environmental performance, company size and corporate social responsibility disclosure on the value of mining companies listed on the Indonesia stock exchange 2015-2019.

In Figure 1 above, the fluctuation of mining commodity prices. One of the causes of the decline in coal commodity prices is due to falling demand, especially from China as the largest coal-consuming country due to low natural gas prices and rampant clean energy policies. China was also reducing the ratio of coal consumption to primary energy consumption from $66 \%$ to $50 \%$ because China was in the spotlight of the world because of its high pollution (Source https://tirto.id/puncak-kegalauanindustri-batu-bara-piP). An increase or decrease in share prices is essential for companies because the higher the share price, the higher its value (Harjito and Martono, 2011). The rise and fall of a public company's stock price in the capital market is an exciting thing to study. The company's stock price is an important concept for investors because its stock price is the primary indicator by which the market can judge it.

According to McWilliams and Siegel (2001), it is stated that financial performance is not sufficient to guarantee the value of the company to grow sustainably. Company sustainability can be realized if the company is concerned about paying attention to and improving the surrounding environment, which is damaged by the company's operational activities, and discloses environmental accounting. It is a form of transparent information that the company has allocated funds for environmental and social sustainability.

Companies that disclose
environmental accounting are considered to have a good image in the public's eyes and have prospects for business sustainability in the future. Investors are also interested in buying more shares. When investing, investors not only look at the results of the company's financial performance. However, investors are also interested in the company's various social, economic, and environmental information in its annual report as a form of company concern for the environment, which will impact the continuity of the company's operational activities. Investors are interested in increasing their investment because the community accepts the company's presence in their environment so that the company's operational activities will run smoothly so that the company can achieve its profit target, which will impact increasing its value itself. So it is expected that accountants can present information on the company's operational activities into financial reports if the company carries out environmental conservation activities so that the reporting made must be based on environmental accounting (Carolina and Martusa, 2011). (Yoshi, 2011) suggests that the accounting system in which there are accounts related to environmental costs is called environmental accounting.

Based on the above phenomenon, disclosing environmental accounting as a form of corporate transparency towards stakeholders in which the company has committed to allocating costs for environmental preservation will impact the company's sustainability and only pursue profit. Therefore, environmental accounting disclosures will be effective in providing information to investors to increase interest in investing to increase company value.

From several previous studies, it was found that there were inconsistencies in research results, namely Sawitri (2017), Suaidah (2018), Aghnia (2018), Ethika et al (2019) and Iqbal e al. (2019), which stated that environmental accounting disclosures had a positive effect on firm value. In contrast, according to Emmanuel et al. (2019), Carandang and Ferrer (2020) stated that environmental accounting disclosure does not affect firm value.

Another factor that affects firm value apart from environmental accounting disclosures is the disclosure of environmental performance. Disclosure of environmental performance is a disclosure of company performance that considers the environment around its operational activities. Companies perform environmental performance to create a good (green) environment (Suratno, 2006). 
Fikry Tanjung et.al. The effect of accounting disclosure and environmental performance, company size and corporate social responsibility disclosure on the value of mining companies listed on the Indonesia stock exchange 2015-2019.

Companies that pay attention to the environment are a form of responsibility and concern for the environment. Especially for the mining sector industry, environmental factors play an important role, and employees are also considered report users. If the company does not pay attention to the surrounding environment in the long term, it can affect its value. It will result in slow or even non-existent growth in company value. In supporting the implementation of environmental responsibility carried out by companies, in 2002, the government, together with the Ministry of Environment (KLH), launched the Company Performance Assessment Program (PROPER) to support companies in managing and structuring the environment through information instruments by actively involving the community (Rakhiemah and Agustia, 2009). The following is a table of the results of the 2015-2019 PROPER assessment as follows:

Table 1 PROPER 2015-2019

\begin{tabular}{|l|l|l|l|l|l|}
\hline YEARS & BLACK & RED & BLUE & GREEN & GOLD \\
\hline $2014-2015$ & 21 & 529 & 1.406 & 108 & 12 \\
\hline $2015-2016$ & 5 & 284 & 1.422 & 172 & 12 \\
\hline $2016-2017$ & 1 & 130 & 1.486 & 150 & 19 \\
\hline $2017-2018$ & 2 & 241 & 1.454 & 155 & 20 \\
\hline $2018-2019$ & 2 & 303 & 1.507 & 174 & 26 \\
\hline
\end{tabular}

From the data in Table 1 above, it can be seen that the development of PROPER continues to increase from year to year. The gold, green and blue ranks tend to increase every year, especially the gold rank, increasing every year. Likewise, black rank continues to decline. It proves that the company increasingly has a sense of responsibility and cares for the environment. Pflieger et al (2005) states that company activities in preserving the environment will bring some benefits, including shareholder and stakeholder interest in company profits due to responsible environmental management. Therefore, there is an influence of environmental performance on company value (Bukit, R. B. et al., 2018. Article IOP Conf. Series: Earth and Environmental Science 122).

Based on the results of previous research, it was found that there were inconsistent research results, namely Auliya (2018), Ethika et al. (2019), and Khanifah et al (2020) stated that environmental performance positively affects firm value. In contrast, according to Sawitri (2017), Hapsoro dan Adyaksana (2020), Arlita (2019), and Zabetha et al (2018), environmental performance do not affect firm value.
Apart from accounting disclosures and environmental performance, company size is also one factor that can influence and determine firm value. Firm value is directly and indirectly influenced by the company's size (Arviansyah, 2013). The company's size is categorized into two types, namely small and large scale companies, which can be seen from the company's total assets. The larger the company's size, the more excellent its opportunity to gain access to funding sources, both internal and external. Company size can be seen from total assets, total net sales, average sales level, and average total assets (Kusumaningrum and Mawardi, 2011). According to Kayobi and Anggraeni (2015), company size can be expressed in total assets, sales, and market capitalization. The greater the total assets, sales, and market capitalization, the greater its size. Large companies can guarantee high company value because large companies dare to invest in company expansion needs. The size of the company can increase the value of the company (Prasetia et al, 2014).

Based on previous research, it was found that there were inconsistent research results, namely Zuhroh (2019), Hirdinis (2019), Nuansari et al (2020), Puteri (2019), Frenky (2019), Riani (2019), which stated 
Fikry Tanjung et.al. The effect of accounting disclosure and environmental performance, company size and corporate social responsibility disclosure on the value of mining companies listed on the Indonesia stock exchange 2015-2019.

that company size had a positive and significant effect on firm value. While according to Cecilia et al. (2016), Karundeng et al. (2017), Sintyana and Artini (2019), Hardian and Asyik (2016), Setiadharma and Machali (2017), Chumaidah and Priyadi (2018) and Purwohandoko (2017), company size has no significant effect on firm value.

The company's sustainability will be guaranteed if the company cares for the community and the surrounding environment. Therefore, companies need to make disclosures about the activities that the company has carried out to the public, which is called Corporate Social Responsibility (CSR). Hendriksen and Nugroho (1994) stated that disclosure presents some information needed to operate an efficient capital market optimally. The concept of CSR reporting refers to the Global Reporting Initiative (GRI) concept, namely the sustainability report concept, which emerged as a result of the concept of sustainability development. The categories of CSR that use the GRI-G4 standard contain six indicators, namely:

1. Economic Performance Indicator

2. Environment Performance Indicator

3. Labor Practices Performance Indicator

4. Human Rights Performance Indicator

5. Social Performance Indicator

6. Product Responsibility Performance Indicator

Currently, CSR is mandatory for limited companies as regulated in Law No. 40 of 2007 concerning Limited Liability Companies. Mining companies are one of the most significant contributors to environmental damage due to their operational activities, so it is necessary to hold CSR as a form of social and environmental responsibility. According to Wijayanti and Prabowo (2011), for companies that disclose more CSR, the company's financial performance tends to be better than companies that do not disclose it. Investors will appreciate the shares of companies that are sustainable and responsible for the environment (Fachrudin Khaira Amalia, article IOP Conf. Series: Earth and Environmental Science 126, 2018) and give a positive response. It can increase the stock price of companies with good environmental performance and vice versa. It will get an inadequate response from investors by decreasing the share price that the company will receive if it has poor environmental performance (Almilia and Wijayanto, 2007). According to Kartini (2009), there are three reasons for business actors to respond and develop CSR issues in line with the company's operational activities, namely:

1. The company is part of the community; therefore, it is only natural that the company pays attention to the interests of the surrounding community;

2. Entrepreneurs and the community around the company should have a symbiotic relationship with mutualism and;

3. Corporate social responsibility activities are one way to reduce and avoid social conflicts.

From several previous studies, it was found that there were inconsistencies in research results, namely Karina and Setiadi (2020), Fauziah et al. (2020), Sabatini and Sudana (2019), Mahendra and Wirawati (2018) stated that CSR disclosure has a positive effect on firm value. While according to Stracia and Junarti (2015), Worokinasih (2020), and Karundeng et al (2017), CSR disclosure has no significant effect on firm value.

\section{Framework}

Following the description of the background of the problem, literature review, and previous research, a conceptual research framework is prepared as follows: 
Fikry Tanjung et.al. The effect of accounting disclosure and environmental performance, company size and corporate social responsibility disclosure on the value of mining companies listed on the Indonesia stock exchange 2015-2019.

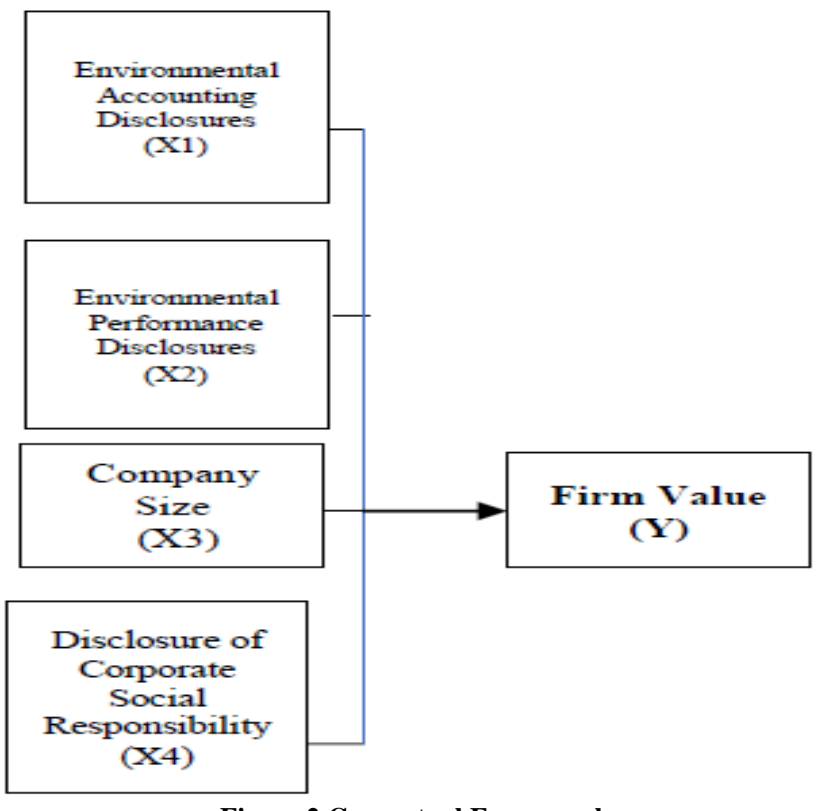

Figure 2 Conceptual Framework

H1: Environmental accounting disclosure has a positive effect on firm value.

$\mathrm{H} 2$ : Environmental performance disclosure has a positive effect on firm value.

H3: Firm size has a positive effect on firm value.

H4: Corporate Social Responsibility has a positive effect on company value.

\section{RESEARCH METHODS}

This type of research is causal associative research to determine the effect of Accounting Disclosure and Environmental Performance, Company Size, and Corporate Social Responsibility
Disclosure on the dependent variable, namely Firm Value. The causal associative study aims to analyze the relationship between one variable and another to know how one variable affects other variables (Erlina, 2011). The data analysis method used in this study is a statistical analysis method using Eviews10 software. Data analysis performs by testing standard assumptions and testing hypotheses.

The population used in this study is 90 mining companies listed on the Indonesia Stock Exchange during the 2015-2019 period. The sampling technique used in this study was purposive sampling.

\section{RESULT AND DISCUSSION}

\section{Normality test}

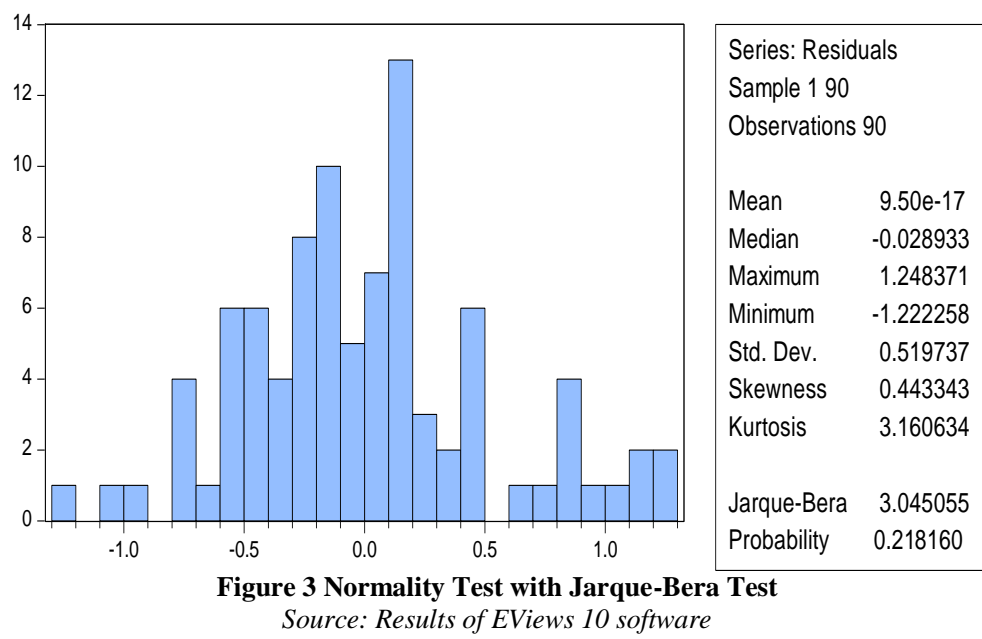


Fikry Tanjung et.al. The effect of accounting disclosure and environmental performance, company size and corporate social responsibility disclosure on the value of mining companies listed on the Indonesia stock exchange 2015-2019.

Based on Figure 3, it is known that the probability value of the J-B statistic is 0.218160 . Because the probability value, which is 0.218160 , is greater than the significance level, which is 0.05 . It means that the assumption of normality is fulfilled.

\section{Determination of the Estimation Model between the Common Effect Model (CEM) and Fixed Effect Model (FEM) with the Chow Test}

Table 2 Results of the Chow Test

\begin{tabular}{|c|c|c|c|}
\hline \multicolumn{3}{|c|}{ Redundant Fixed Effects Tests } & \\
\hline Pool: PANEL & & & \\
\hline \multicolumn{3}{|c|}{ Test cross-section fixed effects } & \\
\hline Effects Test & Statistic & d.f. & Prob. \\
\hline Cross-section F & 0,912331 & $(17,68)$ & 0,5629 \\
\hline Cross-section Chi-square & 18,490873 & 17 & 0,3585 \\
\hline
\end{tabular}

Based on the results of the Chow test in Table 5.5, it is known that the probability value is 0.3585 . Because the probability value is $0.3585>0.05$, the estimation model used is the common effect model (CEM).

Determination of the Estimation Model between the Common Effect Model (CEM) and the Random Effect Model (REM) with the Lagrange Multiplier Test

Table 3 Results of the Lagrange Multiplier Test \begin{tabular}{|l|c|c|c|}
\hline \multicolumn{4}{|l|}{ Breusch-Godfrey Serial Correlation LM Test: } \\
\hline F-statistic & 1,856672 & Prob. F(2,83) & 0,1626 \\
\hline Obs*R-squared & 3,854089 & Prob. Chi-Square(2) & 0,1456 \\
\hline
\end{tabular} \begin{tabular}{l|l|l} 
Obs*R-squared & 3,854089 & Prob \\
Source: Results of EViews 10 software
\end{tabular}

Based on the results of the Lagrange Multiplier test in Table 5.6, it is known that the probability value is 0.1466 . Because of the probability value of $0.1456>0.05$, the estimation model used is the common effect model (CEM).

\section{Hypothesis test}

Table 4 Statistical values of the coefficient of determination, F test, and t-test
\begin{tabular}{|l|l|l|l|l|}
\hline Variable & Coefficient & Std. Error & t-Statistic & Prob. \\
\hline X1 & 0,094888 & 0,123862 & 0,766076 & 0,4458 \\
\hline X2 & $-0,141338$ & 0,077557 & $-1,822387$ & 0,0719 \\
\hline X3 & 0,040617 & 0,070334 & 0,577487 & 0,5651 \\
\hline X4 & $-1,420651$ & 0,546444 & $-2,599812$ & 0,0110 \\
\hline C & $-0,494335$ & 2,025625 & $-0,244041$ & 0,8078 \\
\hline R-squared & 0,133292 & Mean dependent var & $-0,188991$ \\
\hline Adjusted R ${ }^{2}$ & 0,092506 & S.D. dependent var & 0,558274 \\
\hline S.E. of reg & 0,531825 & Akaike info criterion & 1,628950 \\
\hline Sum sr & 24,04125 & Schwarz criterion & 1,767828 \\
\hline Log-likelihood & $-68,30274$ & Hannan-Quinn criter. & 1,684954 \\
\hline F-statistic & 3,268060 & Durbin-Watson stat & 2,169804 \\
\hline Prob(F-stat) & 0,015254 & \multicolumn{4}{|l}{} \\
\hline
\end{tabular}

\section{Analysis of the coefficient of determination}

Based on Table 4, it is known that the coefficient of determination (R-squared) is equal. This value can be interpreted as environmental accounting disclosure, environmental performance disclosure, company size, and corporate social responsibility disclosure simultaneously or jointly affect the firm value by $13.3 \%$. The other factors influence the remaining $86.7 \%$.

\section{Simultaneous Effect Significance Test (Test F)}

Based on Table 4, it is known that the Prob value. (F-statistics), which is
$0.015254<0.05$, it can be concluded that all independent variables, namely environmental accounting disclosure, environmental performance disclosure, company size, and corporate social responsibility disclosure simultaneously, have a significant effect on the firm value variable.

\section{Partial Effect Significance Test (t-test)}

Based on the data in Table 4, the multiple linear regression equation is obtained as follows.

$$
\begin{aligned}
& Y=-0.49+0.094 X 1-0.141 X 2+0.0406 X 3 \\
& -1.420 X 4+e
\end{aligned}
$$


Fikry Tanjung et.al. The effect of accounting disclosure and environmental performance, company size and corporate social responsibility disclosure on the value of mining companies listed on the Indonesia stock exchange 2015-2019.

Based on the data in Table 4, the test results show that environmental accounting disclosure and firm size do not have a significant effect on firm value, environmental performance disclosure has a negative effect on firm value, and disclosure of corporate social responsibility has a significant effect on firm value.

\section{CONCLUSION}

Based on the results of data analysis and research discussion, the following conclusions can be drawn:

1. Based on the F test results, it can be concluded that the environmental accounting disclosure, environmental performance disclosure, company size, and corporate social responsibility disclosure simultaneously have a significant effect on firm value.

2. Environmental accounting disclosure has a positive but insignificant and simultaneous effect on the value of mining companies listed on the IDX in 2015-2019. With transparent environmental accounting disclosures, it can provide a positive response to increasing company value.

3. Disclosure of environmental performance has a negative but insignificant and simultaneous effect on the value of mining companies listed on the IDX in 2015-2019. It is due to the possibility of a shift in the investor's paradigm, in which company performance is inherent in environmental performance. Investors are not too focused on the company's environmental performance through the PROPER assessment so that environmental performance does not affect the company's value.

4. Company size has a positive but not significant and simultaneous effect on the value of mining companies listed on the IDX in 2015-2019. It shows that investors always pay attention to the company's size and how much assets it owns. The bigger the company size, the greater the confidence of investors in investing.

5. Disclosure of corporate social responsibility has a negative but significant and simultaneous effect on the value of mining companies listed on the IDX from 2015 to 2019. It shows that most investors prefer short-term investments rather than long-term investments by simply following the issue. - daily issues that appeared. Corporate social responsibility is a longterm strategy undertaken by the company to maintain the company's continuity. According to the GRI Guidelines, the company does not fully disclose information on corporate social responsibility indicators in every area, such as social, economic, environmental, and human resources.

\section{SUGGESTION}

Based on the analysis results and the conclusions obtained, the researcher suggests that further researchers expand the research object, such as all industrial sectors listed on the IDX, by adding other variables that can affect firm value. For companies, so do not hesitate to disclose environmental accounting and transparent corporate social responsibility to get support from stakeholders and be more attractive to investors.

\section{Acknowledgement: None}

\section{Conflict of Interest: None}

\section{Source of Funding: None}

\section{REFERENCES}

1. Aghnia, F.A. 2018. Pengungkapan Akuntansi Lingkungan Tehadap Kinerja Saham Pada Perusahaan yang Terdaftar di Bursa Efek Indonesia. E-ISSN:2622-304X, P-ISSN: 2622-3031, Vol. 1, No.1.

2. Almilia, L.S., dan Wijayanto, D. 2007. Pengaruh Enviromental Performance dan Enviromental Disclosure terhadap Economic Performance, Accounting Converce. Prosedding: Depok. 
Fikry Tanjung et.al. The effect of accounting disclosure and environmental performance, company size and corporate social responsibility disclosure on the value of mining companies listed on the Indonesia stock exchange 2015-2019.

3. Arlita, I. G. 2019. The effect of Environmental Performance on Firm Value with Good Corporate Governance as a Moderator. The international journal of business and management, ISSN 22318916.

4. Arviansyah, Y. 2013. Pengaruh Struktur Modal, Kinerja Keuangan Perusahaan, Pertumbuhan Perusahaan dan Ukuran Perusahaan Terhadap Nilai Perusahaan pada Perusahaan yang Terdaftar di Jakarta Islamic Index (JII). Skripsi, UIN Syarif Hidayatullah Jakrata.

5. Auliya, M.R., 2018. Pengaruh Kinerja Lingkungan Terhadap Nilai Perusahaan Perusahaan Dengan Corporate Social Responsibility Sebagai Variabel Intervening. Jurnal Manajemen Bisnis Indonesia (JMBI), 7(5), pp.550-558.

6. Bradshaw, C. J., Giam, X., dan Sodhi, N. S. 2010. Evaluating the Relative Environmental Impact of Countries. PLoS ONE, 5(5), e10440.

7. Bukit, R.B., Haryanto, B., Ginting, P. 2018. Environmental performance, profitability, asset utilization, debt monitoring, and firm value. IOP Conf. Series: Earth and Environmental Science 122 - 012137.

8. Carandang, J.C. dan Ferrer, R.C., 2020. Effect of Environmental Accounting on Financial Performance and Firm Value of Listed Mining and Oil Companies in the Philippines". Asia-Pacific Social Science Review 20(1).

9. Carolina, V., Martusa, R. 2011. "Akuntansi Lingkungan: Solusi untuk Problematika Penerapan Corporate Social Responsibility di Indonesia”. Prosiding Seminar Nasional : Problematika Hukum dalam Implementasi Bisnis dan Investasi (Perspektif Multidisipliner).

10. Cecilia, Syahrul Rambe dan Torong, Zainul Bahri. 2016. Analisis Pengaruh Corporate Social Responsibility, Profitability, dan Ukuran Perusahaan Terhadap Nilai Perusahaan pada Perusahaan Perkebunan yang Go Public di Indonesia, Malaysia, dan Singapura. Simposium Nasional Akuntansi (SNA) 18 Medan.

11. Chumaidah, dan Priyadi, M.P. 2018. Pengaruh Profitabilitas dan Size terhadap Nilai Perusahaan dengan CSR sebagai Variabel Pemoderasi. Jurnal Ilmu dan Riset Akuntansi (JIRA), 7(3).
12. Curran, M.A., Pflieger, J., Fischer, M., Kupfer, T. dan Eyerer, P. 2005. The contribution of life cycle assessment to global sustainability reporting of organizations. Management of Environmental Quality: An International Journal.

13. Dody Hapsoro, Rahandhika Ivan Adyaksana. 2020. “Apakah Pengungkapan Informasi Lingkungan Memoderasi Pengaruh Kinerja Lingkungan Dan Biaya Lingkungan Terhadap Nilai Perusahaan". Jurnal Riset Akuntansi Dan Keuangan, 8(1), 2020, 41-52.

14. Elkington, J., 1997. Cannibal with Forks, the Tripple Bottom Line of Twentieth Century Business. Capstone Publishing Ltd, London.

15. Emmanuel, O.G., Elvis, E., Abiola, T., 2019. "Environmental Accounting Disclosure and Firm Value of Industrial Goods Companies in Nigeria." IOSR Journal of Economics and Finance (IOSRJEF). e-ISSN: 2321-5933, p-ISSN: 23215925.Volume 10, Issue 1 Ser. III (Jan. Feb.2019), PP 07-27.

16. Erlina. 2011. Metodologi Penelitian Bisnis untuk Akuntansi dan Manajemen. USU Press, Medan.

17. Ethika, Azwari, M., dan Muslim, R.Y. 2019. Analisis Pengaruh Pengungkapan Akuntansi Lingkungan dan Kinerja Lingkungan terhadap Nilai Perusahaan. Jurnal kajian akuntansi dan auditing, Vol. 14, No. 2.

18. Fachrudin, Khaira Amalia. 2018. Stock Price Analysis of Sustainable Foreign Investment Companies in Indonesia. IOP Conf. Series: Earth and Environmental Science 126 (2018) 012069.

19. Fauziah, D.A., Sukoharsono, E.G., dan Saraswati, E. 2020. Corporate Social Responsibility Disclosure Towards Firm Value: Innovation as mediation. International journal of Research in Business and Social Science (2147-4478), 9(7), 75-83.

20. Ghozali, I. dan A. Chariri. 2007. Teori Akuntansi. Badan Penerbit Universitas Diponegoro Semarang.

21. Hafez, H.M., 2016. Corporate Social Responsibility and Firm Value: an empirical study of an emerging economy. Journal of governance and regulation 5(4), pp.40-53.

22. Hardian, A.P. dan Asyik, N.F., 2016. Kinerja Keungan dan Ukuran Perusahaan 
Fikry Tanjung et.al. The effect of accounting disclosure and environmental performance, company size and corporate social responsibility disclosure on the value of mining companies listed on the Indonesia stock exchange 2015-2019.

Terhadap Nilai Perusahaan, CSR sebagai Variabel Moderasi. Jurnal Ilmu dan Riset Akuntansi (JIRA), 5(9).

23. Hardiyanti, H., 2018. Pengaruh Pengungkapan Akutansi Lingkungan Terhadap Stock Return (Studi Empiris Perusahaan Manufaktur yang Terdaftar di BEI periode 2014-2016).

24. Harjito, Agus dan Martono. 2011. Manajemen Keuangan. Edisi Kedua, Cetakan Pertama, Penerbit EKONISIA, Yogyakarta.

25. Hendriksen, E.S, dan Nugroh, W. 1994. Teori Akuntansi. Edisi ke empat, Jilid 2. Jakarta: Erlangga.

26. Hirdinis. 2019. Capital Structure and Firm Size on Firm Value Moderated by Profitability. International journal of economics and business administration, Vol VII, Issue 1, 2019.

27. Indrajaya, G., dan Setiadi, R. 2011. Pengaruh Struktur Aktiva, Ukuran Perusahaan, Tingkat Pertumbuhan, Profitabilitas dan Risiko Bisnis Terhadap Struktur Modal: Studi Empiris pada Perusahaan Sektor Pertambangan yang Listing di Bursa Efek Indonesia Periode 2004-2007. Akurat Jurnal Ilmiah Akuntansi, 2(06).

28. Iqbal, M., Sutrisno T., Asih, P., dan Rosidi, R. 2013. "Effect of Environmental Accounting Implementation and Environmental Performance and Environmental Information Disclosure as Mediation on Company Value." International Journal of Business and Management Invention ISSN (Online): 2319 - 8028, ISSN (Print): 2319 - 801X, Vol 2 No. 10, Pg.55-67.

29. Karina, D.R.M., dan Setiadi. 2020. Pengaruh CSR terhadap Nilai Perusahaan dengan GCG sebagai Pemoderasi. JRAMB, Prodi Akuntansi, Fakultas Ekonomi, UMB Yogyakarta Volume 6 No. 1, Mei 2020.

30. Kartini, D. 2009. Corporate Social Responsibility: Transformasi Konsep Sustainability Management dan Implementasi di Indonesia, Refika Aditama, Bandung.

31. Karundeng, F., Nangoi, G.B. and Karamoy, H., 2017. Analisis Pengaruh Corporate Social Responsibility Terhadap Nilai Perusahaan dengan Profitabilitas, Kepemilikan Manajemen dan Ukuran Perusahaan sebagai Variabel Moderasi
(Studi Empiris pada Perusahaan Pertambangan yang Terdaftar di Bursa Efek Jakarta tahun 2012-2016). Jurnal Riset Akuntansi Dan Auditing" Goodwill", 8(2).

32. Khanifah, K., Udin, U., Hadi, $\mathrm{N}$ dan Alfiana, F. 2020. Environmental Performance and Firm Value: Testing the Role of Firm Reputation in Emerging Countries. International journal of energy economics and policy, ISSN: 2146-4553.

33. Kusumaningrum, E.A., dan Mawardi 2011. Analisis Pengaruh Profitabiltas, Pertumbuhan Asset, Dan Ukuran Perusahaan terhadap Struktur Modal (Studi Kasus Perusahaan Real Estate dan Property Yang Terdaftar di BEI Tahun 2005-2009).

34. Kayobi, I.G.A., dan Anggraeni, D. 2015. "Pengaruh Debt to Equity Ratio, Debt to Asset, Deviden Tunai dan Ukuran Perusahaan terhadap Nilai Perusahaan (Perusahaan Manufaktur Sektor Barang Konsumsi yang terdaftar di BEI Periode 2011-2014). Jurnal Akuntansi dan Keuangan, Vol. 4, No. 1.

35. Kosimpang, A.D., Andini, R. and Oemar, A., 2017. Pengaruh Profitabilitas, Ukuran Perusahaan terhadap Nilai Perusahaan dengan Variabel Struktur Modal Sebagai Variabel Intervening pada Perusahaan Pertambangan yang Terdaftar di BEI Periode Tahun 2012-2016. Journal Of Accounting, 3(3).

36. Mahendra, I.M.A., dan Wirawati, N.G.P. 2018. Pengaruh Corporate Social Responsibility Terhadap Nilai Perusahaan dengan Profitabilitas dan Free Cash Flow Sebagai Pemoderasi. E-Jurnal Akuntansi, 24(3), 2274-2303.

37. Margono, B.A., Potapov, P.V., Turubanova, S., Stolle, F. dan Hansen, M.C., 2014. Primary forest cover loss in Indonesia over 2000-2012. Nature climate change, 4(8), pp.730-735.

38. McWilliams, A. \& Siegel, D., 2001. Corporate Social Responsibility: A Theory of the Firm Perspective. The Academy of Management Review, 26(1), 117-127.

39. Messwati, E. D. 2012. 70 Persen Kerusakan Lingkungan Akibat Operasi Tambang. Dalam situs resmi KOMPAS.com (www.kompas.com).

40. Nguyen, B.T.N., Tran, H.T.T., Le, O.H., Nguyen, P.T., Trinh, T.H. and Le, V., 2015. Association between corporate social responsibility disclosures and firm value- 
Fikry Tanjung et.al. The effect of accounting disclosure and environmental performance, company size and corporate social responsibility disclosure on the value of mining companies listed on the Indonesia stock exchange 2015-2019.

Empirical evidence from Vietnam. International Journal of Accounting and Financial Reporting, 5(1), pp.212-228.

41. Nuansari, S., Widiastuti, N.P.E., dan Mulyantini, S. 2020. Faktor Yang Mempengaruhi Nilai Perusahaan Dengan Corporate Social Responsibility sebagai Variabel Moderating. SALAM: Jurnal Sosial dan Budaya Syar-i, 7(4), 371-394.

42. Prasetia, T.E., Tommy, P., dan Saerang, I.S. 2014. Struktur modal, ukuran perusahaan dan risiko perusahaan terhadap nilai perusahaan otomotif yang terdaftar di BEI. Jurnal EMBA: Jurnal Riset Ekonomi, Manajemen, Bisnis dan Akuntansi, 2(2).

43. Purwohandoko. 2017. "The influence of firm's size, growth, and profitability on firm value with capital structure as the mediator: a study on the agricultural firms listed in the Indonesian Stock Exchange." International journal of economics and Finance; Vol. 9, No. 8; 2017. ISSN 1916-971X, E-ISSN 1916-9728. Published by Canadian Center of Science and Education.

44. Putu, N.N.G.M., Moeljadi, D., dan Djazuli, A. 2014, "Factor Affecting Firms Value of Indonesia Public Manufacturing Firm" International Journal of Business and Management Invention 3 (2), 35-44.

45. Rakhiemah, A.N dan Agustia, D. 2009. Pengaruh Kinerja Lingkungan terhadap Corporate Social Responsibility (CSR) Disclosure dan Kinerja Financial Perusahaan Manufaktur yang terdaftar di Bursa Efek Indonesia. Simposium Nasional Akuntansi XII, Palembang.

46. Riani, B. 2019. Pengaruh Karakteristik Perusahaan dan Kinerja Lingkungan terhadap Nilai Perusahaan dengan Corporate Social Responsibility (CSR) sebagai Variabel Pemoderasi. Tesis, STIE YKPN Yogyakarta.

47. Rifana, S.R.W, Diana, N., dan Afifudin, A. 2019. Pengaruh Pengungkapan Akuntansi Lingkungan Terhadap Stock Return (Studi Empiris di BEI periode 2016-2018). E-JRA Vol. 08 No. 11 Agustus 2019, Fakultas Ekonomi dan Bisnis Universitas Islam Malang.

48. Sabatini, K., dan Sudana, I.P. 2019. Pengaruh Pengungkapan Corporate Social Responsibility pada Nilai Perusahaan dengan Manajemen Laba sebagai Variabel Moderasi. Jurnal Ilmiah Akutansi dan
Bisnis, Vol. 14, No. 1, Januari 2019, hal 5669.

49. Sawitri, A.P., 2017. Analisis Pengaruh Pengungkapan Akuntansi Lingkungan dan Kinerja Lingkungan terhadap Nilai Perusahaan. In Seminar Nasional \& Call For Paper, FEB Unikma.

50. Setiadharma S dan Machali M, 2017. "The effect of asset structure and firm size on firm value with capital structure as intervening variable." Jurnal of Business \& Financial Affaris.

51. Sintyana, I.P.H. dan Artini, L.G.S., 2018. Pengaruh Profitabilitas, Struktur Modal, Ukuran Perusahaan Dan Kebijakan Dividen Terhadap Nilai Perusahaan. E-Jurnal Manajemen, 8(2), pp.757-785.

52. Sitompul, Puteri Lestari. 2019. FaktorFaktor yang Mempengaruhi Nilai Perusahaan dengan CSR sebagai Variabel Moderating pada Perusahaan Perbankan yang Terdaftar di BEI. Tesis, Fakultas Ekonomi dan Bisnis Universitas Sumatera Utara.

53. Situmorang, Frenky. 2019. Pengaruh Ukuran Perusahaan, Profitabilitas, Pertumbuhan Penjualan dan Good Corporate Governance terhadap Nilai Perusahaan dengan Corporate Social Responsibility sebagai Variabel Moderating pada Perusahaan Perkebunan yang terdaftar di BEI. Tesis, Fakultas Ekonomi dan Bisnis Uversitas Sumatera Utara.

54. Stracia,Evelyn dan Juniarti. 2016. Pengaruh Pengungkapan Corporate Social Responsibility terhadap Nilai Perusahaan di Sektor Pertambangan. Business Accounting Review, Vol. 3, No. 2, Agustus 2015 (8190).

55. Suaidah, Y.M. 2018. Pengaruh Pengungkapan Akuntasi Lingkungan dan Kepemilikan Saham Terhadap Nilai Perusahaan Melalui Kinerja Keuangan. JAD: Journal Riset Akuntansi dan Keuangan Dewantara, 1(2), 105-116.

56. Suka, E.A., 2016. Efektivitas akuntansi lingkungan dalam meningkatkan nilai perusahaan. Universitas Muhammadiyah Yogyakarta, pp.1-24.

57. Suratno. 2006. Pengaruh Environmental Performance terhadap Environmental Disclosure dan Economic Performance. Jurnal Riset Akuntansi Indonesia: 199-241.

58. Susanti, F., Fenny, M. and Rini, I., 2012. The influence of corporate social 
Fikry Tanjung et.al. The effect of accounting disclosure and environmental performance, company size and corporate social responsibility disclosure on the value of mining companies listed on the Indonesia stock exchange 2015-2019.

responsibility on firm value with profitability and leverage as a moderating variable. Proceeding the $13^{\text {th }}$ Malaysia Indonesia Conference on Economics, Management and Accounting (MICEMA) 2012.

59. Wijayanti, F.T., dan Prabowo M.A. 2011. Pengaruh Corporate Social Responsibility Terhadap Kinerja Keuangan Perusahaan. Aceh: Simposium Nasional Akuntansi XIV, 1-29.

60. Worokinasih, S., dan Zaini, M.L.Z.B.M. 2020. The Mediating Role of Corporate Social Responsibility (CSR) Disclosure on Good Corporate Governance (GCG) and Firm Value. A Technical Note. Australasian Accounting, Business and Finance Journal, 14(1), 88-96.

61. Yoshi. A. 2011. Peran Akuntansi Lingkungan Dalam Meningkatkan Kinerja Lingkungan dan Kinerja Perusahaan. Berkala Ilmiah Mahasiswa Akuntansi. Vol. 1, No.1.
62. Zabetha, O., Tanjung, A.R., dan Savitri, E. 2018. Pengaruh Corporate Governance, Kinerja Lingkungan dan Kinerja Keuangan terhadap Nilai Perusahaan dengan Pengungkapan CSR sebagai Variabel Moderating (Studi pada perusahaan pertambangan yang terdaftar di BEI periode 2012-2014). Jurnal ekonomi, vol 26, No. 1.

63. Zuhroh, I. 2019. The effects of Liquidity, Firm Size and Profitability on the Firm Value with Mediating Leverage. KnE Social Sciences, 203-230.

How to cite this article: Tanjung F, Rina $\mathrm{Br}$ Bukit, Fachrudin KA. The effect of accounting disclosure and environmental performance, company size and corporate social responsibility disclosure on the value of mining companies listed on the Indonesia stock exchange 20152019. International Journal of Research and Review. 2021; 8(4): 149-160. DOI: https:// doi.org/10.52403/ijrr.20210421 